\title{
PHYSICAL EXERCISE AND FUNCTIONAL CAPACITY IN ELDERLY FROM THE SOUTH TRIANGLE HEALTH REGIONAL - MINAS GERAIS STATE, BRAZIL: EVALUATION BY GENDER
}

\author{
EXERCÍCIO FÍSICO E CAPACIDADE FUNCIONAL EM IDOSOS NA REGIONAL \\ DE SAÚDE TRIÂNGULO DO SUL - MINAS GERAIS: AVALIAÇÃO POR GÊNERO
}

\author{
Álvaro Silva SANTOS ${ }^{1}$; Érica Midori IKEGAMI² Jéssica Rodrigues de ALMEIDA $^{3}$; \\ Michelle Helena Pereira de PAIVA ${ }^{4}$; Rodrigo Eurípedes da SILVEIRA ${ }^{5}$ \\ 1. Nurse. Public Health Specialist. Master in Health Services Management. PhD in Social Sciences. Post-doctor in Social Work. \\ Associate Professor at Universidade Federal do Triangulo Mineiro (UFTM), Uberaba, Minas Gerais. alvaroenf@hotmail.com 2. \\ Physical Therapist. Elderly Health Specialist, Master's degree in Health Care at UFTM. erica.ikegami@ gmail.com. 3. Physical \\ Therapist, Elderly Health Specialist, almeidajessica10@ hotmail.com. 4. Occupational Therapist. Elderly Health Specialist. Master in \\ Health Care. mhppaiva@gmail.com 5. Nurse. Master in Health Sciences. PhD Student in Sciences from Coordination of Disease \\ Control of Health Secretariat of Sao Paulo State. rodrigoeuripedes.silveira@gmail.com
}

\begin{abstract}
The aim of this study was to verify the functional capacity between genders as well as the practice of physical exercises in accordance with procedures among elderly people from municipalities in the South Triangle, Minas Gerais, Brazil. Data relating to the practice of physical exercise and functional capacity were obtained by means of a structured questionnaire and the Katz scale, respectively. It was found that most of the elderly was independent to carry out the activities of daily life, even if they were not adept at exercising. Women showed a higher dependency level compared to men. As regards the modalities of exercise and those who practice them, men prefer to walk and swim, while women prefer aerobics and weight training. These results allow concluding that elderly respondents do not practice the modalities under study (walking, aqua aerobics, weight training and swimming), although they are independent to daily life activities. Regular and supervised exercise programs are recommended for elderly of all age groups, with a view to promoting a better quality of life and preventing functional incapacity.
\end{abstract}

KEYWORDS: Elderly. Exercise. Motor Activity.

\section{INTRODUCTION}

Elderly population in Brazil is increasing in a much accelerated way. According to data from Brazilian Institute of Geography and Statistics, in the National Research for Sample of domiciles (IBGE, PNAD, 2012) in 2012, the number of elderly has doubled in the last 20 years, summing up 23.5 millions of the Brazilians.

The higher contingent of this population is represented by female individuals, due to social transitions and the increase in life expectancy for this gender (KUCHEMANN, 2012; RODRIGUES, NERI, 2012). In this context it is important to highlight the repercussions of the morphological and functional alterations as a result of the aging process (SILVA, GOULART, LANFERDINI, et al., 2012). As people age they become less active and their physical capacity decrease facilitating the emergence of chronic diseases which contribute to accelerate the aging process (BORGES, MOREIRA, 2009), what refers to a condition of dependency to perform daily living activities (CARMO, MENDES, BRITO, 2008).

Functional incapacity is defined by the presence of difficulty, need for help or impossibility of performing daily living activities (DLA), instrumental activities of daily living (IADL) and mobility activities (ALVES, LEITE, 2010; DEL DUCA, SILVA, SILVA, et al., 2011). Dependence for the performance of such activities by the elderly is related to the worsening of the physical and mental health, as well as increased demand for health services and high indexes of institutionalization (ROSSO, EATON, WALLACE, et al., 2013).

For the evaluation of the elderly functional capacity lots of studies have adopted performance tests (direct observation) or scales, such as Katz's (ASSIS, MARTA, CONTI, et al., 2014), due to their ease. When evaluating functional capacity it is also verified the importance of identifying factors associated with the commitment, such as gender and increase in age (SILVA, MENEZES, 2014). According to GONÇALVES, SILVA, MAZO, et al. (2010) information obtained with this evaluation makes possible the specific interventions to be directed and the follow up of cases, with the goal of preventing the decline of physical aptitude and functional capacity, resulting from the aging itself.

Much of the elderly physical capacity decline is because of the inactivity due to the 
atrophy in disuse resulting from sedentary lifestyle (VIRTUOSO JÚNIOR, TRIBESS, PAULO, et al., 2012). In this context, practice of physical exercise, when well oriented and regularly performed, can generate a number of benefits such as the increase/maintenance of muscle mass, improvement of cardiorespiratory fitness, prevention of chronic non-communicable diseases, reduction of anxiety and depression, among others (MACIEL, 2010). According to BORGES and MOREIRA (2009) benefits resulting from regular physical activities practice have been studied by many researchers because it contributes to the maintenance of the quality of life of older people.

Thus, the aim of this study was to verify the functional capacity between genders as well as the practice of physical exercises in accordance with procedures among elderly people from municipalities in the South Triangle, Minas Gerais, Brazil.

\section{MATERIAL AND METHODS}

It is a population-based cross-sectional study with a descriptive and quantitative approach. This study is part of a Project "Health Profile of the elderly population from the municipalities of Regional Superintendent for Health Uberaba/MG", Brazil, State Health Department (SES/MG) and City Health Departments of the municipalities involved 3430 males and females participated in the study, living in 24 municipalities from South Triangle: Água Comprida, Araxá, Campo Florido, Campos Altos, Carneirinho, Comendador Gomes, Conceição das Alagoas, Conquista, Fronteira, Frutal, Ibiá, Itapagipe, Iturama, Limeira do Oeste, Pedrinópolis, Perdizes, Pirajuba, Planura, Pratinha, Sacramento, Tapira, Uberaba, União de Minas and Veríssimo. Delta, São Francisco de Sales and Santa Juliana municipalities were part of a Pilot Project; therefore, their results were not focused in this study. Sample size was defined based on a simple randomized sampling with no replacement, considering the proportion of senior citizens of each municipality and assuming a maximum error of $5 \%$ between the proportion found in the sample and the true population proportion, with a significance level of $5 \%$. The sample consisted of individuals who met the following inclusion criteria: subjects of both genders, aged 60 years or over, residing in the municipalities surveyed during the period in question, who do not present cognitive decline, able to walk to the local data collection and agree to participate in the survey with the signing of the informed consent (IC). This study is part of a major project which was approved by the Research Ethics Committee, under Protocol No 1640/2010.

Data collection took place in the homes of the elderly and in public places offered by the City Hall of cities. Data collection was held from May 2012 to April 2013. The instruments used for data collection were the Katz scale for assessment of activities of daily life and a structured questionnaire with questions relating to modalities (walking, aerobics, swimming, weight training or other) for evaluation of the practice of physical exercises, noting that the practice of walking was considered as exercise when performed over 30 minutes.

For evaluation of functional capacity was used the scale of Independence in activities of daily living of KATZ (KATZ, FORD, MOSKOWITZ, et al., 1963) drawn by KATZ and adapted in Brazil by LINO (LINO, PEREIRA, CAMACHO, et al., 2008). The scale investigates the activities of selfcare: bathing, dressing, going to the bathroom, lie down and get up out of bed, eat and control of urination functions and/or evacuate.

The statistical analyses were carried out in Statistical Package for Social Sciences (SPSS) version 20.0. The data were presented in descriptive statistics (mean, standard deviation and frequency).

The analysis of scale of Katz was held from the score of each basic activity of daily living evaluated and also according to the total score. For each activity was considered the score zero (independence), one (partial dependence) and two (total dependence) (MACIEL, GUERRA, 2007). The overall rating was analysed dichotomous form: independence (without any difficulty in activities) versus dependence (partial/total dependency to perform one or more activities) (FREITAS, FERNANDES, COQUEIRO, 2012).

Analyses were performed by using relative frequency and chi-square test for the association of the variables studied $(\mathrm{p}<0.05)$.

\section{RESULTS}

Study participants were 3430 elderly of both genders and it was observed the predominance of female subjects, corresponding to 61.5 of total participants. Related to the distribution in age groups, most subjects of both genders were between 60-69, followed by the range of 70-79 years and finally 80 years or more, with a predominance of females in all groups, as shown in Table 1. 
Table 1. Characterization of the sample by gender and age group. Regional Health South Triangle, Minas Gerais, Brazil, 1st half of 2013.

\begin{tabular}{lrrrr}
\hline & \multicolumn{2}{c}{ Male } & \multicolumn{2}{c}{ Female } \\
Age group & $\mathrm{N}$ & $\%$ & $\mathrm{~N}$ & $\%$ \\
\cline { 2 - 5 } 60 - 69 years & 620 & 47.0 & 1185 & 56.1 \\
70 - 79 years & 516 & 39.1 & 703 & 33.3 \\
80 years or over & 183 & 13.9 & 223 & 10.6 \\
Total & 1319 & 100.0 & 2111 & 100.0 \\
\hline
\end{tabular}

With respect to the level of independence for bathing, dressing, toileting, transfer/moving, be continent and feeding it generally turns out that most of the elderly is independent to carry out these activities.

Among the activities presented, both men $(99.4 \%)$ as women $(99.2 \%)$ showed more independence to perform the item to go to the bathroom. In all activities, women showed some level of dependency (partial dependent and dependent) towards men, but these values did not have statistical significance $(\mathrm{p}<0.05)$. Related to the continence, there was a predominance of the level of independence in males $(\mathrm{p}<0.001)$, according to Table 2 .

Table 2. Performance in daily life activities by gender, according to Katz's scale. Regional Health South Triangle, Minas Gerais, Brazil, 1st half of 2013.

\begin{tabular}{|c|c|c|c|c|c|c|}
\hline \multirow[t]{2}{*}{ Activities } & & \multicolumn{2}{|c|}{ Male } & \multicolumn{2}{|c|}{ Female } & \multirow[t]{2}{*}{$\mathbf{P}$} \\
\hline & & $\mathrm{N}$ & $\%$ & $\mathrm{~N}$ & $\%$ & \\
\hline \multirow[t]{3}{*}{ Bath } & Independent & 1288 & 97.6 & 2045 & 96.9 & 0.412 \\
\hline & Partial dependent & 20 & 1.5 & 37 & 1.8 & \\
\hline & Dependent & 11 & 0.8 & 27 & 1.3 & \\
\hline \multirow[t]{3}{*}{ Get dressed } & Independent & 1287 & 97.6 & 2049 & 97.1 & 0.359 \\
\hline & Partial dependent & 17 & 1.3 & 27 & 1.3 & \\
\hline & Dependent & 14 & 1.1 & 33 & 1.6 & \\
\hline \multirow[t]{3}{*}{ Go to the bathroom } & Independent & 1311 & 99.4 & 2095 & 99.2 & 0.898 \\
\hline & Partial dependent & 7 & 0.5 & 13 & 0.6 & \\
\hline & Dependent & 1 & 0.1 & 3 & 0.1 & \\
\hline \multirow{3}{*}{$\begin{array}{l}\text { Transference/ } \\
\text { Locomotion }\end{array}$} & Independent & 1308 & 99.2 & 2084 & 98.7 & 0.326 \\
\hline & Partial dependent & 11 & 0.8 & 25 & 1.2 & \\
\hline & Dependent & 0 & 0.0 & 0 & 0.0 & \\
\hline \multirow[t]{3}{*}{ Continence } & Independent & 1227 & 93.0 & 1788 & 84.7 & 0.001 \\
\hline & Partial dependent & 86 & 6.5 & 303 & 14.4 & \\
\hline & Dependent & 6 & 0.5 & 20 & 1.0 & \\
\hline \multirow[t]{3}{*}{ Feeding } & Independent & 1306 & 99.0 & 2090 & 99.0 & 0.890 \\
\hline & Partial dependent & 11 & 0.8 & 17 & 0.8 & \\
\hline & Dependent & 2 & 0.2 & 4 & 0.2 & \\
\hline
\end{tabular}


The Table 3 presents the modalities of physical exercises more practiced by elderly according to the gender. It can be observed that most of the elderly do not practice physical exercise. In relation to the adherents to the exercise, the modalities more practiced both by men and by women are in this order: walking, aqua aerobics, weight training and finally, swimming.
In addition, there were more men who practiced walking (47.0\%) and swimming (2.5\%) towards women, and these, in turn, practice more aqua aerobics (7.8\%) and weight training (4.0\%) in relation to men; however this difference between the procedures by gender was small.

Table 3. Exercising for modalities and gender. Regional Health South Triangle, Minas Gerais, Brazil, 1st half of 2013.

\begin{tabular}{|c|c|c|c|c|c|c|}
\hline \multicolumn{2}{|l|}{ Modality } & \multicolumn{2}{|c|}{ Male } & \multicolumn{2}{|c|}{ Female } & \multirow[t]{2}{*}{$\mathbf{p}$} \\
\hline & & $\mathrm{N}$ & $\%$ & $\mathrm{~N}$ & $\%$ & \\
\hline \multirow[t]{2}{*}{ Walking } & Yes & 620 & 47.0 & 838 & 39.7 & $<0.001$ \\
\hline & No & 699 & 53.0 & 1273 & 60.3 & \\
\hline \multirow[t]{2}{*}{ Aqua aerobics } & Yes & 44 & 3.3 & 164 & 7.8 & $<0.001$ \\
\hline & No & 1275 & 96.7 & 1947 & 92.2 & \\
\hline \multirow[t]{2}{*}{ Swimming } & Yes & 33 & 2.5 & 39 & 1.8 & 0.193 \\
\hline & No & 1286 & 97.5 & 2072 & 98.2 & \\
\hline \multirow[t]{2}{*}{ Weight training } & Yes & 38 & 2.9 & 85 & 4.0 & 0.079 \\
\hline & No & 1281 & 97.1 & 2026 & 96.0 & \\
\hline
\end{tabular}

\section{DISCUSSION}

In Brazil, the population aging is occurring so rapidly, due to the decrease in the fertility rate and increased longevity rate of the population (Instituto de Saúde Suplementar, 2013). Given the importance of these epidemiological changes and the impact of physiological changes of aging, currently there are several studies with the elderly population, including seniors in the age groups of this study such as works by ASSIS, MARTA, CONTI, et al., (2014) and VIRTUOSO, MAZO, MENEZES, et al. (2012). It was found that among the 3430 elderly, 2111 were women, what characterizes the "feminization of aging" (GOLDANI, 1999), present in studies on population aging and in other studies with the elderly in which the samples were also constituted predominantly by females (SILVA, MENEZES, 2014; ROCHA, ALMEIDA, ARAÚJO, et al., 2013). Over the course of five decades, the number of men in relation to the number of women decreased (INSITUTO BRASILEIRO DE GEOGRAFIA E
ESTATÍSITICA, 2010), what can be justified by the greater life expectancy of women and also by specific behaviors of genders. The prevalence of alcoholism, smoking and involvement in traffic accidents is higher in men. However, the frequency in medical centers and the continuous medical follow-up are higher in females (KUCHEMANN, 2012).

Despite this higher life expectancy, researchers like DEL DUCA, SILVA, SILVA, et al. (2011) observed the association between female and functional incapacity. In this study it was found in the comparison between the genders, a greater number of dependent women to carry out the activities of daily life. In studies of prevalence of functional incapacity, rates are more significant in older women due to their longevity, which justifies the fact they bear a greater burden of chronic disease conditions, causing a most important functional decline (LIMA, BUENO, 2009; PEREIRA, BASTOS, DEL DUCA, et al., 2012). According to DUARTE, ANDRADE; LEBRÃO (2007) continence refers to the self- 
regulated act of urinating and defecating, without presenting partial or total incontinence and external control as catheterization, enemas or use of diapers. In this study, women were more dependent on the item continence compared to men. Such dependence can be explained by risk factors that women have for urinary incontinence, such as parity and menopause and for fecal incontinence the risk of pudendal nerve injury or the anal sphincter by obstetric injury and genital dystopias (HIGA, LOPES, 2005; OLIVEIRA, PINTO-NETO, CONDE, et al., 2006).

Despite the greater disability among women in this study both genders showed significant levels of independence to carry out the six activities, as well as in the study of FERREIRA, MACIEL, COSTA, et al., (2012), who examined the determinants of active ageing and its relationship with functional independence. Probably this is due to one of the inclusion criteria of the study, which the elderly should be able to walk to the place of interview.

According to the results presented, the preference for physical exercises most prevalent mode in both genders was in that order: walking, aqua aerobics, weight training and swimming. In accordance with SALVADOR, KINGS; FLORINDO (2009), walking, the most practical modality among the elderly is a potentially more accessible physical activity, safe, low cost, which brings a number of benefits as aerobic conditioning, muscle strengthening and flexibility, which explains the greater adherence of the population to this practice, as noted in this study. In addition, it is easy to be incorporated into the daily lives of the elderly, because it requires no special equipment, can be practiced individually or collectively; so it is better suited to programs related to health promotion.

Concerning aqua aerobics, the second most prevalent modality, the main motivational factors to its practice are the improvement of physical and mental health. Most seniors who practice aqua gym feature high self-esteem and self-image, indicating that physical exercises in water can provide physical and psychosocial benefits for the elderly (CARDOSO, MAZO, PRADO, et al., 2008). The physical properties that water offers, enables the development of other motor skills like strength, flexibility and aerobic capacity (NUNES, SANTOS, 2009).

Domingues and Neri (2009) found that the most cited physical exercise in their study was walking (36.8\%). Another study which examined the practice of physical activity beyond hydrogymnastics, found that $78.3 \%$ performed another activity, especially walking (56.7\%) (CARDOSO, MAZO, PRADO, et al., 2008). Such findings show that some researchers have found results similar to this study, in which the elderly studied have preference for walking and water aerobics regardless of gender.

Most of the elderly respondents did not engage in physical exercises and according to Maciel (2010) this context may be due to technological development which provided greater convenience to life, greater domestic leisure experience, resulting from the increased insecurity and the emptying of public spaces; lack of spaces and community leisure facilities that allow the practice of physical activities. Thus, although the majority of participants said they do not practice exercise, a significant number of the elderly respondents presented themselves independent to carry out the activities of daily life. This may be explained by the completion of other activities such as domestic, religious and leisure, that assist in maintaining functional capacity (FERREIRA, MACIEL, COSTA, et al., 2012).

For Maciel (2010), physical activity is defined as any bodily movement produced by skeletal muscles that results in energy expenditure greater than resting levels, for example: walking, dancing, gardening, climbing stairs, among other activities; and physical exercise is understood as all physical activity planned, structured and repetitive aimed at the improvement and maintenance of one or more components of physical fitness.

This question encompasses the term "active ageing", in which the term active is related not only to physical exercise, but also the involvement of the elderly in social, economic, cultural, spiritual and civil issues (WORLD HEALTH ORGANIZATION, 2005). Although this study did not have evaluated other types of activities that elderly performs, studies show that seniors can remain independent and active physically and mentally through domestic activities such as taking care of the house and the grandkids and leisure activities (FERREIRA, MACIEL, SILVA, et al., 2010; NOGUEIRA, RIBEIRO, ROSADO, et al., 2010). So, the elderly of this study were not adept at exercising, but can perform physical activities, which prevent the functional decline.

Although it is evident that a large part of the population studied is not adept at exercising, it should be noted that this is important for a healthy and independent aging (CARDOSO, MAZO, PRADO, et al., 2008). Functional capacity is one of the factors that contribute to a better quality of life for elderly (MACIEL, 2010), therefore, exercise 
should be encouraged because it helps to soften the physiological changes of aging process, as well as prevent the functional decline and the onset of diseases (GREMEAUX, GAYGA, LEPERS, et al., 2012).

Most of the elderly respondents were independent, which was one of the limitations of this study, because to participate in the survey the elderly person could not have cognitive deficit and should be able to walk to data collection location. In addition, it was not evaluated domestic, religious and leisure activities, among others, which could justify the independence of the elderly for daily life activities even if they do not practice physical exercise.

This study found the practice of physical exercise according to modalities (walking, aqua aerobics, weight training and swimming) and the functional capacity of older people of both genders. By analyzing the sample, it was verified by the study and confirmed with the literature, the significant number of female elderly. When comparing performance to carry out the activities of daily life between genders, it was found that the woman is more dependent. As regards the modalities of exercise and those who practice them, men prefer to walk and swim, while women prefer aerobics and weight training.

\section{FINANCIAL SUPPORT}

This study had financial support from Fundação de Amparo à Pesquisa de Minas Gerais (FAPEMIG).

RESUMO: O objetivo desse estudo foi verificar a capacidade funcional entre os gêneros, bem como a prática de exercícios físicos segundo modalidades em idosos de municípios do Triângulo do Sul, Minas Gerais. Os dados referentes à prática de exercício físico e capacidade funcional foram obtidos através de um questionário estruturado e pela Escala de Katz, respectivamente. Verificou-se que grande parte dos idosos era independente para a realização das atividades de vida diária, mesmo não sendo adeptos a prática de exercício físico. As mulheres apresentaram nível de dependência maior em comparação aos homens. No que se refere às modalidades de exercícios, e daqueles que a realizam, os homens tem preferência pela caminhada e natação, enquanto as mulheres por hidroginástica e musculação. Estes resultados permitem concluir que os idosos respondentes não são adeptos das modalidades em estudo (caminhada, hidroginástica, musculação e natação), apesar de serem independentes para atividades de vida diária. Programas de exercícios orientados são recomendados para que o idoso alcance maior qualidade de vida e previna a incapacidade funcional.

PALAVRAS-CHAVE: Idoso. Exercício. Atividade Motora.

\section{REFERENCES}

ALVES, L. C.; LEITE, I. C.; Machado, C. J. Fatores associados à incapacidade funcional dos idosos no Brasil: análise multinível. Revista de Saúde Pública, São Paulo, v. 44, n. 3, p. 468-478, 2010. Retrieved June 30, 2014, from http://www.scielo.br/scielo.php?script=sci_arttext\&pid=S0034$89102010000300010 \& \operatorname{lng}=$ en\&tlng=pt. 10.1590/S0034-89102010005000009.

ASSIS, V. G.; MARTA, S. N.; CONTI, M. H. S.; GATTI, M. A. N.; SIMEÃO, S. F. A. P.; VITTA, A. Prevalência e fatores associados à capacidade funcional de idosos na Estratégia Saúde da Família em Montes Claros, Minas Gerais, Brasil. Revista Brasileira de Geriatria e Gerontologia, Rio de Janeiro, v. 17, n. 1, p. 153-163, 2014. Retrieved June 30, 2014, from http://www.scielo.br/scielo.php?script=sci_arttext\&pid=S180998232014000100153\&lng=en\&tlng=pt. 10.1590/S1809-98232014000100015.

BORGES, M. R. D.; MOREIRA, A. K. Influências da prática de atividades físicas na terceira idade: estudo comparativo dos níveis de autonomia para o desempenho nas AVDs e AIVDs entre idosos ativos fisicamente e idosos sedentários. Revista Motriz, Rio Claro, v. 15, n. 3, p. 562-573, 2009. Retrieved June 30, 2014, from http://cac-php.unioeste.br/extensao/unati/arqs/UNATI_14.pdf

CARDOSO, A. S.; MAZO, G. Z.; PRADO, A. P. M.; LEVANDOSKI, G.; CARDOSO, L. S. Comparação do nível de atividade física em relação ao gênero de idosos participantes de grupos de convivência. RBCEH, Passo Fundo, v. 5, n. 1, p. 9-18, 2008. Retrieved June 30, 2014, from http://www.upf.br/seer/index.php/rbceh/article/view/99/175 
CARMO, N. M.; MENDES, E. L.; BRITO, C. J. Influência da atividade física nas atividades da vida diária de idosas. RBCEH, Passo Fundo, v. 5, n.2, p. 16-23, 2008. Retrieved June 30, 2014, from http://www.upf.br/seer/index.php/rbceh/article/view/108/243

DEL DUCA, G. F.; SILVA, M. C.; SILVA S. G.; NAHAS, M. V.; HALLAL, P. C. Incapacidade funcional em idosos institucionalizados. Revista Brasileira de Atividade Física e Saúde, Pelotas, v. 16, n. 2, p. 120-124, 2011. Retrieved June 25, 2014, from http://periodicos.ufpel.edu.br/ojs2/index.php/RBAFS/article/viewFile/569/569

DOMINGUES, P. C.; NERI, A. L. Atividade física habitual, sintomas depressivos e doenças auto-relatadas em idosos da comunidade. Revista Brasileira de Atividade Física e Saúde, Pelotas, v. 14, n. 3, p. 164-173, 2009. Retrieved June 15, 2014, from http://periodicos.ufpel.edu.br/ojs2/index.php/RBAFS/article/viewFile/770/779

DUARTE, Y. A. O.; ANDRADE, C. L.; LEBRÃO, M. L. O Índex de Katz na avaliação da funcionalidade dos idosos. Revista da Escola de Enfermagem da USP, São Paulo, v. 41, n. 2, p. 317-325, 2007. Retrieved June 30, 2014, from http://www.scielo.br/scielo.php?script=sci_arttext\&pid=S0080$62342007000200021 \& \operatorname{lng}=$ en\&tlng=pt. 10.1590/S0080-62342007000200021.

FERREIRA, O. G. L.; MACIEL, S. C.; SILVA, A. O.; SANTOS, W. S.; MOREIRA, M. A. S. P. O envelhecimento ativo sob o olhar de idosos funcionalmente independentes. Revista da Escola de Enfermagem da USP, São Paulo, v. 44, n. 4, p. 1065-1069, 2010. Retrieved June 30, 2014, from http://www.scielo.br/scielo.php?script=sci_arttext\&pid=S0080-62342010000400030\&lng=en\&tlng=pt. 10.1590/S0080-62342010000400030.

FERREIRA, O. G. L.; MACIEL, S. C.; COSTA, S. M. G.; SILVA, A. O.; MOREIRA, M. A. S. P. Envelhecimento ativo e sua relação com a independência funcional. Texto e Contexto Enfermagem, Florianópolis, v. 21 n. 3, p. 513-518, 2012. Retrieved June 30, 2014, from http://www.scielo.br/scielo.php?script=sci_arttext\&pid=S0104-07072012000300004\&lng=en\&tlng=pt. 10.1590/S0104-07072012000300004.

FREITAS, R. S.; FERNANDES, M. H.; COQUEIRO, R. D. S.; REIS JÚNIOR, W. M.; ROCHA, S. V., BRITO, T. A. Capacidade funcional e fatores associados em idosos: estudo populacional. Acta Paul Enferm, São Paulo, 2012; 25(6):933-9. http://dx.doi.org/10.1590/S0103-21002012000600017

GOLDANI, A. M. Mulheres e envelhecimento: desafios para novos contratos intergeracionais e de gênero. In CAMARANO, A. A. (org.). Muito além dos sessenta: os novos idosos brasileiros. Rio de Janeiro: IPEA, 1999. p. 75-114.

GONÇALVES, L. H. T.; SILVA, A. H.; MAZO, G. Z.; BENEDETTI, T.R.B.; SANTOS, S. M. A.; MARQUES, A.; RODRIGUES, R. A. P.; PORTELLA, M. R.; SCORTEGAGNA, H. M.; SANTOS, S. S. C.; PELZER, M. T.; SOUZA A. S.; MEIRA, E. C.; SENA, E. L. S.; CREUTZBERG, M.; REZENDE T. L. O idoso institucionalizado: avaliação da capacidade funcional e aptidão física. Cadernos de Saúde Pública, São Paulo, v. 26 n. 9, p. 1738-1746, 2010. Retrieved June 30, 2014, from http://www.scielo.br/scielo.php?script=sci_arttext\&pid=S0102-311X2010000900007\&lng=en\&tlng=pt. 10.1590/S0102-311X2010000900007.

GREMEAUX, V.; GAYGA, M.; LEPERS, R.; SOSNER, P.; JUENAU, M.; NIGAM, A. Exercise and longevity. (2012). Maturitas, Amsterdan, v. 73, n. 4, p. 312-317, 2012. Retrieved July 01, 2014, from http://www.maturitas.org/article/S0378-5122(12)00301-5/fulltext.

http://dx.doi.org/10.1016/j.maturitas.2012.09.012

HIGA, R.; LOPES, M. H. B. M. Fatores associados com a incontinência urinária na mulher. Revista Brasileira de Enfermagem, Brasília, v. 58, n. 4, p. 422-428, 2005. Retrieved June 30, 2014, from http://www.scielo.br/scielo.php?script=sci_arttext\&pid=S0034-71672005000400008\&lng=en\&tlng=pt. 10.1590/S0034-71672005000400008. 
INSTITUTO BRASILEIRO DE GEOGRAFIA E ESTATÍSTICA (IBGE). Pesquisa Nacional de Amostra por Domicílio (PNAD), 2012. Retrieved from June 30, 2014, from http://www.ibge.gov.br

INSTITUTO BRASILEIRO DE GEOGRAFIA E ESTATÍSTICA (IBGE). Censo demográfico: Brasil, 2010. Retrieved from June 30, 2014, from http://www.ibge.gov.br

INSTITUTO DE ESTUDOS DE SAÚDE SUPLEMENTAR. Envelhecimento populacional e os desafios para o sistema de saúde brasileiro [recurso eletrônico] / Instituto de Estudos de Saúde Suplementar - São Paulo: IESS, 2013.

KATZ, S.; FORD, A. B.; MOSKOWITZ, R. W.; JACKSON, B. A.; JAFFE, M. W. Studies of Illness in the Aged. The Index of Adl: A Standardized Measure of Biological and Psychosocial Function. JAMA.1963; v. 185, p. 914-9. http://dx.doi.org/10.1001/jama.1963.03060120024016

KÜCHEMANN, B. A. Envelhecimento populacional, cuidado e cidadania: velhos dilemas e novos desafios. Sociedade e Estado, Brasília, v. 27, n. 1, p. 165-180, 2012. Retrieved June 30, 2014, from http://www.scielo.br/scielo.php?script=sci_arttext\&pid=S0102-69922012000100010\&lng=en\&tlng=pt. 10.1590/S0102-69922012000100010.

LIMA, L. C. V.; BUENO, C. M. L. B. Envelhecimento e Gênero: a vulnerabilidade de idosas no Brasil. Revista Saúde e Pesquisa, Maringá, v. 2, n. 2, p. 273-280, 2009. Retrieved June 30, 2014, from http://www.cesumar.br/pesquisa/periodicos/index.php/saudpesq/article/view/1173/792.

LINO, V. T. S.; PEREIRA, S. R. M.; CAMACHO, L. A. B.; RIBEIRO FILHO, S. T.; BUKSMAN, S. Adaptação transcultural da Escala de Independência em Atividades da Vida Diária (Escala de Katz). Cadernos de Saude Publica, Rio de Janeiro, 2008; v. 24, n. 1, p. 103-12. http://dx.doi.org/10.1590/S0102311X2008000100010

MACIEL, Á. C. C.; GUERRA, R. O. Influência dos fatores biopsicossociais sobre a capacidade funcional de idosos residentes no nordeste do Brasil. Rev Bras Epid. 2007; v. 10, n. 2, p. 178-89.

http://dx.doi.org/10.1590/s1415-790x2007000200006

MACIEL, M. G. Atividade física e funcionalidade no idoso. Revista Motriz, Rio Claro, v. 16, n. 4, p. 10241032, 2010. Retrieved June 30, 2014, from http://www.periodicos.rc.biblioteca.unesp.br/index.php/motriz/article/view/19806574.2010v16n4p1024/pdf_23

NOGUEIRA, S. L.; RIBEIRO, R. C. L.; ROSADO, L. E. F. P. L.; FRANCESCHINI, S. C. C.; RIBEIRO, A. Q.; PEREIRA, E. T. Fatores determinantes da capacidade funcional em idosos longevos. Brazilian Journal of Physical Therapy, São Carlos, v. 14, n. 4, p. 322-329, 2010. Retrieved July 01, 2014, from http://www.scielo.br/scielo.php?script=sci_arttext\&pid=S1413-35552010000400009\&lng=en\&tlng=pt. 10.1590/S1413-35552010005000019. http://dx.doi.org/10.1590/S1413-35552010005000019

NUNES, M. E. S.; SANTOS, S. Avaliação funcional de idosos em três programas de atividade física: caminhada, hidroginástica e Lian Gong. Rev. Port. Cien. Desp, Porto, v. 9, n. 2-3, p. 150-159, 2009. Retrieved June 30, 2014, from http://www.scielo.gpeari.mctes.pt/scielo.php?script=sci_arttext\&pid=S1645$05232009000300003 \& \operatorname{lng}=\mathrm{pt}$.

OLIVEIRA, S. C. M.; PINTO-NETO, A. M.; CONDE, D. M; GÓES, J. R. N.; SANTOS-SÁ, D.; COSTAPAIVA, L. Incontinência fecal em mulheres na pós-menopausa: prevalência, intensidade e fatores associados. Arquivos de Gastroenterologia, São Paulo, v. 43, n. 2, p. 102-106, 2006. Retrieved May 30, 2014, from http://www.scielo.br/scielo.php?script=sci_arttext\&pid=S0004-28032006000200008\&lng=en\&tlng=pt. 10.1590/S0004-28032006000200008. 
PEREIRA, G. N.; BASTOS, G. A. N.; DEL DUCA, G. F.; BÓS, A. J. G. Indicadores demográficos e socioeconômicos associados à incapacidade funcional em idosos. Cadernos de Saúde Pública, Rio de Janeiro, v. 28, n. 11, p. 2035-2042, 2012. Retrieved July 20, 2014, from http://www.scielo.br/scielo.php?script=sci_arttext\&pid=S0102-311X2012001100003\&lng=en\&tlng=pt. 10.1590/S0102-311X2012001100003

ROCHA, S. V.; ALMEIDA, M. M. G.; ARAÚJO, T. M.; SANTOS, L. B.; RODRIGUES, W. K. M. Fatores associados à atividade física insuficiente no lazer entre idosos. Revista Brasileira de Medicina do Esporte, São Paulo, v. 19, n. 3, p. 191-195, 2013. Retrieved June 30, 2014, from http://www.scielo.br/scielo.php?script=sci_arttext\&pid=S1517-86922013000300009\&lng=en\&tlng=pt.

RODRIGUES, N. O.; NERI, A. L. Vulnerabilidade social, individual e programática em idosos da comunidade: dados do estudo FIBRA, Campinas, SP, Brasil. Ciência e Saúde Coletiva, Rio de janeiro, v. 17, n. 8, p. 2129-2139, 2012. Retrieved June 30, 2014, from http://www.scielo.br/scielo.php?script=sci_arttext\&pid=S1413-81232012000800023\&lng=en\&tlng=pt. 10.1590/S1413-81232012000800023.

ROSSO, A. L.; EATON, C. B.; WALLACE, R.; GOLD, R.; STEFANICK, M. L.; OCKENE, J. K.; CURB, J. D.; MICHAEL, Y. L. Geriatric Syndromes and Incident Disability in Older Women: Results from the Women's Health Initiative Observational Study. J Am Geriatr Soc, Malden, v. 61, n. 3, p. 371-379, 2013. Retrieved June 30, 2014, from http://www.ncbi.nlm.nih.gov/pmc/articles/PMC3602348/pdf/nihms425461.pdf . http://dx.doi.org/10.1111/jgs.12147

SALVADOR, E. P.; REIS, R. S.; FLORINDO, A. A. A prática de caminhada como forma de deslocamento e sua associação com a percepção do ambiente em idosos. Revista Brasileira de Atividade Física e Saúde, Pelotas, v. 14, n. 3, p. 197-205, 2009. Retrieved June 30, 2014, from http://periodicos.ufpel.edu.br/ojs2/index.php/RBAFS/article/viewFile/774/783

SILVA, M. F.; GOULART, N. B. A.; LANFERDINI, F. J.; MARCON, M.; DIAS, C. P. Relação entre os níveis de atividade física e qualidade de vida de idosos sedentários e fisicamente ativos. Revista Brasileira de Geriatria e Gerontologia, Rio de Janeiro, v. 15, n. 4, p. 634-642, 2012. Retrieved June 30, 2014, from http://www.scielo.br/scielo.php?script=sci_arttext\&pid=S1809-98232012000400004\&lng=en\&tlng=pt. 10.1590/S1809-98232012000400004.

SILVA, N. A.; MENEZES, T. N. Capacidade funcional e sua associação com idade e sexo em uma população idosa. Revista Brasileira de Cineantropometria e Desempenho Humano, Florianópolis, v. 16, n. 3, p. 359370, 2014. Retrieved June 30, 2014, from http://www.scielo.br/scielo.php?script=sci_arttext\&pid=S1980$00372014000300359 \& \operatorname{lng}=$ en\&tlng=pt. 10.5007/1980-0037.2014v16n3p359.

VIRTUOSO JÚNIOR, J. S.; TRIBESS, S.; PAULO, T. R. S.; MARTINS, C. A.; PEREZ, V. R. Atividade física como indicador preditivo para incapacidade funcional em pessoas idosas. Rev. Latino-Am. Enfermagem, Ribeirão Preto, v. 20, n. 2, p. 259-265, 2012. Retrieved June 30, 2014, from http://www.scielo.br/pdf/rlae/v20n2/pt_07.pdf.

VIRTUOSO, J. F.; MAZO, G. Z.; MENEZES, E. C.; CARDOSO, A. S.; DIAS, R. G.; BALBÉ, G. P. Perfil de morbidade referida e padrão de acesso a serviços de saúde por idosos praticantes de atividade física. Ciência e Saúde Coletiva, Rio de Janeiro, v. 17, n. 1, p. 23-31, 2012. Retrieved July 20, 2014, from http://www.scielo.br/scielo.php?script=sci_arttext\&pid=S1413-81232012000100005\&lng=en\&tlng=pt. 10.1590/S1413-81232012000100005.

WORLD HEALTH ORGANIZATION. Envelhecimento ativo: uma política de saúde / World Health Organization; tradução Suzana Gontijo. - Brasília: Organização Pan-Americana da Saúde. 2005. 